\title{
Obituary
}

Prof. M. S. Pembrey, F.R.S.

$\mathrm{M}$ ARCUS SEYMOUR PEMBREY succeeded Starling as professor of physiology at Guy's Hospital, London, in 1899 and retired after thirty-four years at that post last year. For most of this time he lived on a small farm in Sussex, which with little help but that of his family he worked himself. It was almost a principle with him that the physiological life could be lived only in the country, and even then only by those who, so far as possible, produce the food necessary for their own life. He seemed to enjoy the sturdiest of health and it was a great shock for his friends to hear of his death, at the age of sixty. eight years, in a nursing home at Oxford on July 23, barely a year since his retirement to a farm in Wychwood Forest on the Cotswolds.

Pembrey, after graduating in medicine at Oxford in 1892 , worked with $J$. S. Haldane in Burdon Sanderson's laboratory for three years, and was then appointed lecturer in physiology in the Charing Cross Hospital Medical School, where he stayed until he went to Guy's four years later.

The work which Pembrey began with Haldane at Oxford he continued for some years after he moved to London; in fact, throughout his whole career the field in which he worked, though its boundaries grew, was essentially the same. In his early work, by weighing the carbonic acid expired, he studied the reaction of animals to changes in external temperature, and was able to trace the acquirement of the power of regulating body temperature. For this he compared the chick before hatching and at different intervals after it, and also new-born mammals and the same animals some days later.

Some of Pembrey's most interesting observations were on the respiratory activity of hibernating animals, dormice, bats, hedgehogs and marmots, during their sleep, during the process of waking and after it. He recorded the type of respiratory movements, the activity of respiratory exchange and the relation between the carbonic acid formed and oxygen used. This relation, the 'respiratory quotient', he found to be far lower during the winter sleep than was compatible with the complete oxidation of foods; some intermediate product of oxidation was retained in the body : on the other hand, during the period before the sleep came on, when the animal was putting on fat, it was higher than the oxidations alone could account for. He was convinced and stoutly maintained to the end that these facts necessitated the belief that, in the former condition, fat was being converted into glycogen and in the latter the converse change was occurring. These views he supported by many other experiments.

Later, Pembrey was one of the first to seize upon the methods introduced by Haldane and his pupils for obtaining alveolar air and collecting the whole expired air from a man in all sorts of circumstances, to study the respiratory activity of men during exertion, in the state of 'second wind', and also in various pathological conditions.
In 1898 Pembrey contributed two important chap. ters to Sharpey-Schafer's "Textbook of Physiology" on the chemistry of respiration and on animal heat respectively. These will always be valuable to students of nineteenth century physiology. They were subjects which he had even then made his own, and on which all his most important later work had direct bearing.

\section{Mr. J. W. E. Heath}

THE death occurred, on July 24, at Oxhey, Herts, after a brief illness, of Mr. John William E. Heath, at the age of seventy-eight years. A Londoner, he was born in 1856 at 33 Upper Gloucester Place, Dorset Square. He retired from staff duties at the Royal Institution in 1925, after forty-six years' service, which began with an engagement as a junior helper in the laboratory there, entering with some previous apprenticeship in assaying. In later times he acted as lecturer's assistant in the historic lecture theatre. Heath had in turn seen eight years' service with Prof. Tyndall, thirty-six years' with Sir James Dewar, and two years' with Sir William Bragg.

As the helper and advisor of two generations of the leading men of science in their lectures and accompanying experimental demonstrations at the Institution, it would be true to say that he was eminently successful. Of placid disposition, endowed with abounding patience, he was specially competent to carry out the varied duties falling within this particular sphere of work. Elected into the Chemical Society so far back as 1891, Heath's certificate for fellowship stated that he had had great experience as an assistant, and had given valuable aid in all the original investigations conducted at the Royal Institution for the previous ten years. The signatures appended were: James Dewar, F. A. Abel, G. D. Liveing, W. C. Roberts-Austen, Ludwig Mond.

Heath lost an eye in an explosion of a glass cylinder at the Royal Institution (about 1904), during the course of experimental work for the purification of helium (tediously accumulated from the $0 \cdot 1$ per cent source from the King's Well, Bath). This misfortune he bore with a calm philosophy, not unmixed with an amused sense of the impeachment of friends that one eye seemed to serve him equally as two. He had held an appointment as a gas examiner under the Hertfordshire County Council for an extended period, and was, in fact, at work in such capacity to within ten days of his death.

We regret to announce the following deaths:

Sir Edgeworth David, K.B.E., C.M.G., emeritus professor of geology in the University of Sydney, known for his work in the Antarctic and on the geology of Australia, on August 28, aged seventy-six years.

Prof. Carl Jensen, director of the Serum Laboratory in the Royal Danish Veterinary and Agricultural Institute, Copenhagen, a pioneer in cancer research, on September 3, aged seventy years. 